\title{
PENGEMBANGAN E-MODULE BERMUATAN MODEL PERUBAHAN KONSEPTUAL DALAM PEMBELAJARAN FISIKA DI SMA
}

\author{
I Made Wena \\ Program Studi Pendidikan Matematika Unmas Denpasar
}

\begin{abstract}
In this study has successfully developed a prototype e-module used conceptual change models physics learning in high school. E-module prototype is successfully developed produced in the form of compact disk $(C D)$ and also have the internet at http://www.dewena.com. In terms of content, development of a prototype e-module uses user friendly approach with a model of Conceptual Interactive Instruction (ICI) with only limited material on the subject of straight line motion and newtons law of motion. Feasibility evaluation of the prototype e-module generated by the formative testing conducted by involving experts and users as well as summative testing of significance based on the difference between the average pretest and posttest scores. Feasibility evaluation results show that the average score of the feasibility of an $e$ module prototype that provided by experts and users is of 3.78 with very good categories. While summative testing showed an average pretest score of 5.35 with a standard deviation of 0.87 and the average posttest score of 8.40 with a standard deviation of 0.68. By the t-test, obtained that for the 95\% confidence level of the average pretest score and the average posttest scores differed significantly, meaning that students' learning achievement after using the e-module is better than before using the e-module.
\end{abstract}

Key words : physical e-module, learning model, conseptual change

\section{PENDAHULUAN}

\section{Latar Belakang Masalah}

Perkembangan teknologi komputer yang semakin pesat telah mampu mendorong percepatan penggunaan komputer dalam pembelajaran sebagai bagian dalam perkembangan teknologi informasi. Seirama dengan perkembangan teknologi tersebut, maka penggunaan teknologi informasi sebagai bagian dalam media pembelajaran diyakini dapat mempengaruhi pencapaian kompetensi peserta didik dalam mengikuti proses pembelajaran. Penggunaan e-module, di samping karena alasan biaya yang relatif lebih murah jika dibandingkan dengan teknologi cetak, juga karena alasan lain yang lebih mendasar, yaitu pengembangan sumber daya manusia di bidang Teknologi Informasi (TI). Jika e-module dapat dikembangkan dan 
digunakan sebagai fasilitas belajar siswa di sekolah, akan ada suatu nilai tambah yang signifikan, tidak hanya terhadap peningkatan kualitas proses dan produk belajar bidang studi, tetapi juga peningkatan kompetensi siswa di bidang TI.

Fenomena yang cukup menyedihkan, adalah bahwa Indonesia mengalami kesenjangan teknologi atau digital divide. Kesenjangan ini disebabkan oleh karena tidak mampunya sebagian besar masyarakat Indonesia untuk menikmati teknologi. Kondisi ini semakin menyedihkan manakala dunia pendidikan indonesia juga belum banyak yang memanfaatkan e-module sebagai media pembelajaran.

Persoalan mendasar yang perlu dicermati tentang belum populernya penggunaan $e$-module dalam pembelajaran adalah minimnya prototipe-prototipe $e$ module yang berhasil dikembangkan. Salah satu penyebabnya adalah rendahnya kemampuan berkolaborasi antar programmer, teknolog pembelajaran, ahli pengajaran bidang studi, dan ahli-ahli lainnya yang mendukung diterapkannya $e$ module sebagai fasilitas belajar siswa.

Penelitian ini menggagas pengembangan e-module untuk pembelajaran dengan mengambil sampel materi fisika sebagai konten e-module. Sedangkan strategi penyajian materi pembelajaran dalam e-module menggunakan model perubahan konseptual. Pengembangan e-module ini dilaksanakan dengan pemberdayaan potensi kolaboratif antar programmer, ahli media pembelajaran, fisikawan yang mendukung akselerasi penerapan e-module di dunia pendidikan khususnya dalam pembelajaran bidang studi fisika.

\section{Ruang lingkup dan batas-batas penelitian}

Penelitian pengembangan dan evaluasi e-module fisika bemuatan model perubahan konseptual dalam pembelajaran fisika ini hanya mencakup pengembangan prototipe. Dalam pengembangan dan evaluasi e-module fisika, digunakan software open source moodle, dengan model Interactive Conceptual Instruction (ICI). Walaupun dalam penelitian ini, prototipe e-module hanya dikembangkan dalam lingkup pembelajaran fisika, namun pada pengembangan berikutnya dapat dilakukan adaptasi untuk pembelajaran bidang studi yang lain dan bahkan mencakup e-module yang lengkap untuk siswa SMA dari berbagai tingkatan kelas.

Pengimplementasian program dilakukan di localhost dengan Apache sebagai server. Lingkup program aplikasi pendukung lainnya, meliputi : macromedia 
dreamweaver, PhotoShop, dan Flash. Implementasi desain model pembelajaran yang dikembangkan dalam penelitian ini, mencakup: (1) program (software) home page dari model pembelajaran berbasis e-learning, (2) program (software) antarmuka (interface) dari model pembelajaran berbasis TI, yang berfungsi untuk menginterkoneksikan antar halaman-halaman modul, dan (3) program (software) dari setiap halaman modul dari seluruh materi yang ingin ditampilkan berkaitan dengan model pembelajaran berbasis e-learning.

Keterbatasan penelitian lainnya, adalah : (1) Proses validasi produk hanya dilaksanakan oleh tim peneliti di localhost dengan melibatkan siswa, guru, ahli TIK, ahli programmer, ahli teknologi pembelajaran, ahli media pembelajaran, ahli pembelajaran fisika. (2) Uji coba teknis hanya meliputi uji melalui jaringan internet yaitu dengan cara upload seluruh file yang telah diimplementasikan. (3) Sosialisasi model hanya dilakukan pada guru fisika dan siswa SMA Negeri di Provinsi Bali. (4) Evaluasi model hanya ditinjau dari dua segi, yaitu Try Out dan Implementasi model.

\section{Tujuan Penelitian}

Tujuan umum jangka panjang yang ingin dicapai dalam penelitian ini adalah melakukan aksi dukungan terhadap program e-learning, khususnya aksi pengembangan dan evaluasi e-module di dunia pendidikan dengan menghasilkan produk e-module fisika bermuatan model perubahan konseptual untuk pembelajaran fisika di SMA. Sedangkan tujuan khusus penelitian adalah (1) Menghasilkan prototipe e-module fisika bermuatan model perubahan konseptual untuk pembelajaran fisika pada jenjang pendidikan SMA yang dapat diadaptasi kembali oleh siapa saja, di mana saja, dan kapan saja untuk pengajaran bidang studi yang lain dan untuk jenjang kelas dan jenjang pendidikan yang berbeda dan (2) Menguji cobakan prototipe e-module fisika bermuatan model perubahan konseptual untuk pembelajaran fisika di SMA pada tataran formative testing dan summative testing, dengan tujuan untuk menilai kelayakan pakai dan kelayakan diadaptasi kembali dari prototipe produk e-module fisika bermuatan model perubahan konseptual dalam pembelajaran fisika di SMA. 


\section{Manfaat Penelitian}

Pengembangan e-module fisika bermuatan model perubahan konseptual secara umum bertujuan mewujudkan fasilitas e-learning. Secara prinsip, e-module memberikan manfaat secara fleksibel, mengakomodasi belajar mandiri, dan efesiensi biaya pendidikan.

Manfaat fleksibilitas mengandung makna, bahwa e-module memberikan fleksibilitas dalam memilih waktu dan tempat untuk mengakses pelajaran. Siswa tidak perlu mengadakan perjalanan menuju tempat pelajaran disajikan, belajar bisa dilakukan dari mana saja baik yang memiliki akses ke Internet ataupun tidak. Manfaat fleksibiltas tersebut di dukung juga oleh perkembangan teknologi informasi saat ini, di mana berbagai tempat sudah menyediakan sambungan internet/hot spot gratis menggunakan wi-fi atau wimax.

Manfaat mengakomodasi belajar mandiri mengandung makna, bahwa $e$ module memberikan kesempatan bagi siswa secara mandiri memegang kendali atas keberhasilan belajar mereka. Siswa bebas menentukan kapan akan mulai, kapan akan menyelesaikan, dan bagian mana dalam suatu materi pelajaran yang ingin dipelajarinya terlebih dulu. Seandainya, setelah diulang masih ada hal yang belum ia pahami, siswa bisa menghubungi instruktur, nara sumber melalui email, chat atau ikut dialog interaktif pada waktu-waktu tertentu. Bisa juga membaca hasil diskusi di message board yang tersedia di LMS (Learning Management System).

Manfaat efesiensi biaya pendidikan dengan e-module dapat dirasakan oleh penyelenggaran pendidikan dan bagi siswa. Bagi penyelenggara pendidikan, dalam hal ini sekolah, biaya yang bisa dihemat antara lain: (1) Biaya pengelolaan bias ditekan, biaya guru pengajar menjadi lebih efesien, (2) penyediaan sarana dan fasilitas fisik untuk belajar (misalnya: penyewaan ataupun penyediaan ruang kelas, kursi, papan tulis, LCD player, OHP).

Dengan e-module, efesiensi biaya dan waktu dapat diwujudkan, karena materi pelajaran dapat didistribusikan baik secara on-line maupun off-line ke sekolahsekolah atau ke rumah-rumah. Dengan demikian, pembelajaran akan bisa berlangsung secara in time. 


\section{KERANGKA TEORI}

\section{Model Pembelajaran Perubahan Konseptual}

Model pembelajaran merupakan kerangka konseptual yang melukiskan prosedur yang sistematis dalam mengorganisasikan pengalaman belajar untuk mencapai tujuan belajar. Jadi model pembelajaran cenderung preskriptif, yang relatif sulit dibedakan dengan strategi pembelajaran. Burden dan Byrd (1999:85) menyatakan An instructional strategy is a method for delivering instruction that is intended to help students achieve a learning objective. Model pembelajaran perubahan konseptual merupakan satu model pembelajaran yang memiliki kecenderungan berlandaskan paradigma konstruktivistik. Model pembelajaran ini memberikan landasan pikir bahwa pengetahuan yang telah dimiliki oleh seseorang sesungguhnya berasal dari pengetahuan yang secara spontan diperoleh dari interaksinya dengan lingkungan. Sementara pengetahuan baru dapat bersumber dari intervensi di sekolah yang keduanya bisa konflik, kongruen, atau masing-masing berdiri sendiri.

Dalam kondisi konflik kognitif, siswa dihadapkan pada tiga pilihan, yaitu: (1) mempertahankan intuisinya semula, (2) merevisi sebagian intuisinya melalui proses asimilasi, dan (3) merubah pandangannya yang bersifat intuisi tersebut dan mengakomodasikan pengetahuan baru. Perubahan konseptual terjadi ketika siswa memutuskan pada pilihan yang ketiga. Menurut Brook (1993), agar terjadi proses perubahan konseptual, belajar semestinya melibatkan pembangkitan dan restrukturisasi konsepsi-konsepsi yang dibawa oleh siswa sebelum pembelajaran. Sedangkan menurut Santyasa (2004), model pembelajaran perubahan konseptual memiliki enam langkah pembelajaran, yaitu: (1) Sajian masalah konseptual dan kontekstual, (2) konfrontasi miskonsepsi terkait dengan masalah-masalah tersebut, (3) konfrontasi sangkalan berikut strategi-strategi demonstrasi, analogi, atau contohcontoh tandingan, (4) konfrontasi pembuktian konsep dan prinsip secara ilmiah, (5) konfrontasi materi dan contoh-contoh kontekstual, (6) konfrontasi pertanyaanpertanyaan untuk memperluas pemahaman dan penerapan pengetahuan secara bermakna. 


\section{E-Module dan pembelajaran Mandiri}

Sistem pembelajaran yang sudah umum kita alami dan dilakukan selama ini adalah sistem pembelajaran melalui tatap muka antara guru dengan siswa di dalam suatu ruangan kelas. Melalui pembelajaran konvensional sikap kemandirian belajar siswa kurang terpacu. Untuk mengatasi kondisi tersebut dikembangkan pola pembelajaran e-learning dengan salah satu aplikasinya dapat dilakukan melalui pembelajaran menggunakan e-module. Pembelajaran dengan e-module merupakan pembelajaran dengan menggunakan modul yang dalam implementasinya memanfaatkan media elektronik, terutama pemanfaatan sistem jaringan komputer, baik dalam bentuk local area network maupun internet.

Pembelajaran dengan e-module dapat meningkatkan motivasi belajar siswa atau peserta didik secara mandiri. Belajar mandiri merupakan upaya metodis dan sistematis yang dilakukan oleh peserta didik dalam mangatur proses pembelajarannya dalam rangka mewujudkan pencapaian penguasaan kompetensi belajarnya secara utuh. Wedemeyer dalam Keegan (1983) mengemukakan peserta didik yang belajar secara mandiri mempunyai kebebasan untuk belajar tanpa harus menghadiri pelajaran yang diberikan pengajar di kelas. Peserta didik dapat mempelajari pokok bahasan atau topik pelajaran tertentu dengan membaca buku atau melihat dan mendengarkan program media pandangdengar (audio visual) tanpa bantuan atau dengan bantuan terbatas dari orang lain, serta peserta didik mempunyai otonomi dalam belajar.

Kemandirian dalam belajar ini perlu diberikan kepada peserta didik supaya mereka mempunyai tanggung jawab dalam mengatur dan mendisiplinkan dirinya dan dalam mengembangkan kemampuan belajar atas kemauan sendiri. Sikap-sikap tersebut perlu dimiliki peserta didik karena hal tersebut merupakan ciri kedewasaan orang dalam pembelajaran.

Melalui pembelajaran dengan menggunakan e-module peserta didik diberikan kesempatan yang seluas-luasnya untuk ikut menentukan tujuan, sumber, dan evaluasi belajarnya. Dengan demikian peserta didik memiliki tanggung jawab 
tersendiri dalam mengatur dan mendisiplinkan dirinya dalam belajar, tanpa harus terikat pada kondisi pembelajaran secara konvensional.

\section{Pengembangan e-module bermuatan model perubahan konseptual}

Berbicara tentang strategi pengembangan e-module, maka pada hakekatnya sama dengan strategi pengembangan perangkat lunak. Dalam ilmu rekayasa perangkat lunak (software engineering), ada minimal lima tahapan yang harus kita lalui dalam mengembangkan sebuah $e$-module, yaitu : (1) tahapan analisis kebutuhan dan spesifikasi, (2) tahapan desain, (3) tahapan coding, (4) tahapan testing, dan (5) tahapan perawatan.

Kelima tahapan dalam pengembangan e-module merupakan langkah-langkah yang mesti dilakukan dengan sebaik-baiknya untuk mendapatkan hasil pengembangan e-module yang berkualitas dan sesuai dengan kebutuhan. Melalui tahapan-tahapan tersebut dikembangkan dan dilakukan analisis yang akurat terkait apakah e-module yang dibuat benar-benar merupakan suatu kebutuhan dan bersesuaian dengan target pembelajaran yang ingin dicapai. Apabila salah dalam melakukan tahapan analisa kebutuhan dan spesifikasi yang berarti tidak berhasil melakukan capture tentang apa sebenarnya yang menjadi kebutuhan dari pengguna (user needs), maka telah menandakan kegagalan dalam pengembangan e-module, yang berimplikasi fatal pada ketidak bermanfaatan e-module yang dihasilkan.

\section{METODE PENELITIAN}

\section{Rancangan Penelitian dan Implementasi Desain}

Rancangan penelitian dalam pengembangan e-module fisika bermuatan model perubahan konseptual menggunakan pendekatan user friendly, artinya Home Page yang menjadi ujung tombak dari model, dapat memberikan gambaran tentang model secara menyeluruh dan siapapun yang mengakses diharapkan tidak mengalami kesulitan. Software sebagai dasar e-learning dikembangkan dengan menggunakan bahasa PHP dan dikembangkan dalam model Interactive Conceptual Instruction (ICI).

Sistem e-module dikendalikan oleh seorang administrator dengan Pengguna e-module dibedakan atas 3 kelompok, yaitu (1) pengajar, (2) siswa, dan (3) tamu. Untuk melakukan kontrol terhadap pengguna tamu, maka pengguna ini hanya 
diberikan hak akses pada bagian-bagian tertentu saja dari informasi yang ada. pengajar dan siswa diberikan hak akses yang seluas-luasnya sesuai dengan fungsi masing-masing. Untuk melakukan kontrol terhadap peran pengajar dan siswa, maka masing-masing pengajar dan masing-masing siswa harus memiliki name account dan password tersendiri. Pola pendaftaran pengguna dilakukan dengan dua cara, yaitu pendaftaran yang dilakukan melalui administrator pembelajaran dan pendaftaran yang dilakukan secara on-line melalui internet.

Implementasi desain $e$-module fisika bermuatan model perubahan konseptual menggunakan program aplikasi open source moodle dengan aplikasi pendukung program Dreamweaver sebagai editor PHP dengan MySQL sebagai databasenya. Pengimplementasian program dilakukan di localhost dengan menggunakan Web Server Apache dan dipublikasikan di dunia internet dengan menggunakan nama domain dan hosting tertentu.

\section{Rencana Penelitian}

Penelitian ini menggunakan pendekatan Research and development (R\&D) dalam pengembangan e-module fisika bermuatan model perubahan konseptual, dengan menggunakan model desain instruksional Dick \& Carey (1990).

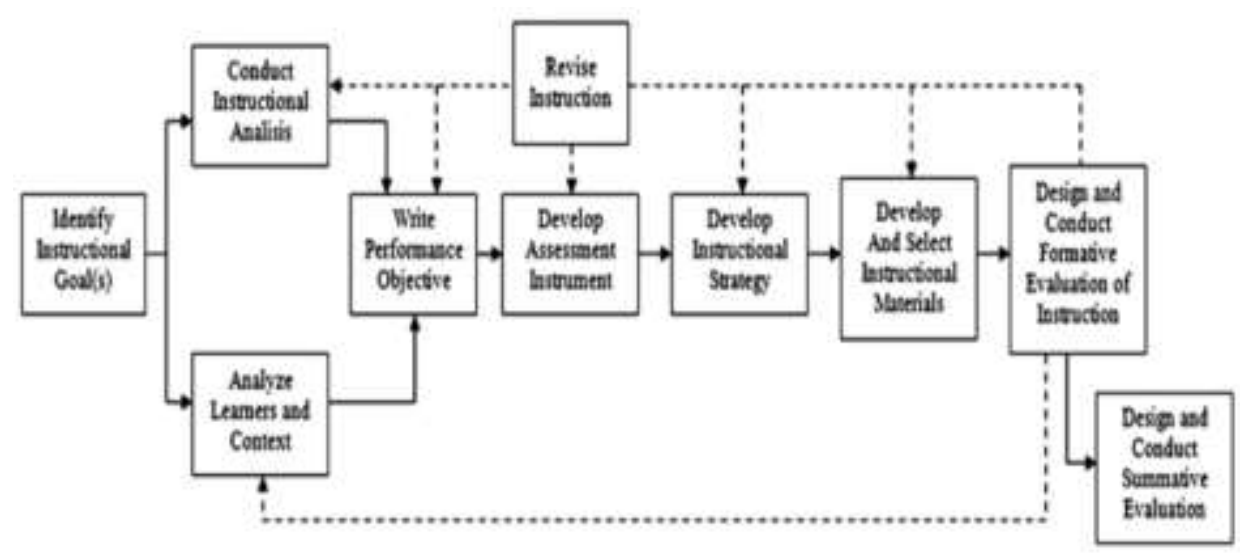

Gambar 01 : Desain instruksional Dick \& Carey

\section{Sampel Penelitian}

Pada tahapan pengembangan produk melibatkan sampel sebanyak 34 orang, dengan komposisi seorang ahli desain e-module, seorang ahli programmer, seorang ahli teknologi pembelajaran, seorang ahli media pembelajaran, seorang ahli 
pembelajaran fisika, sebanyak 9 orang guru-guru fisika SMA sebagai praktisi dan pemakai, dan sebanyak 20 orang siswa-siswa SMA sebagai pemakai.

\section{Metode Pengumpulan Data dan Instrumen}

Data penelitian dikumpulkan dengan menggunakan instrumen dalam bentuk angket dan pretest/posttes. Angket dipergunakan untuk mengumpulkan data tentang tanggapan sampel terhadap prototipe e-module yang dihasilkan. Tanggapan meliputi segi kecepatan dan ketepatan program, segi praktisnya penggunaan produk oleh siswa dan guru, serta segi manfaat produk untuk pengembangan e-learning pembelajaran fisika. Angket dibedakan atas : angket penilaian ahli $e$-module, angket penilaian ahli programmer, angket penilaian ahli teknologi pembelajaran, angket penilaian ahli media pembelajaran, angket penilaian ahli desain, angket penilaian ahli pembelajaran fisika SMA, angket penilaian oleh guru, dan angket penilaian oleh siswa. Pengumpulan data uji coba prototipe menggunakan pretest dan posttes pelajaran fisika.

\section{Pengolahan dan Analisis Data}

Data penelitian diolah dengan cara mengelompokkan data berdasarkan unitnya. Setelah data dikelompokkan berdasarkan unitnya, selanjutnya dilakukan tabulasi. Hasil tabulasi tersebut ditransformasi ke skala standar. Data tanggapan terhadap prototipe e-module melalui formatif testing di analisis dengan secara deskriptif sedangkan data hasil uji coba implementasi e-module di analisis dengan mempergunakan uji-t.

Hasil analisis selanjutnya dipergunakan sebagai dasar memberikan justifikasi terhadap kualitas kelayakan pengembangan prototipe produk e-module fisika yang dihasilkan.

\section{HASIL DAN PEMBAHASAN}

\section{Hasil Pengembangan Prototipe e-module Fisika}

Bertitik tolak pada tujuan penelitian dan target penelitian, maka telah berhasil dikembangkan prototipe e-module Fisika bermuatan model perubahan konseptual 
dalam pembelajaran Fisika di SMA. Prototipe $e$-module yang berhasil dikembangkan diproduksi dalam bentuk compact disk (CD) pembelajaran dan juga telah di posting di internet. Dari segi konten, pengembangan prototipe e-module fisika ini menggunakan pendekatan user friendly dengan model Interactive Conceptual Instruction (ICI) dengan materi hanya dibatasi pada pokok bahasan gerak lurus dan hukum newton tentang gerak.

Screenshot halaman utama dari produk prototipe $e$-module fisika bermuatan model perubahan konseptual yang berhasil dikembangkan dapat dilihat pada gambar 02.

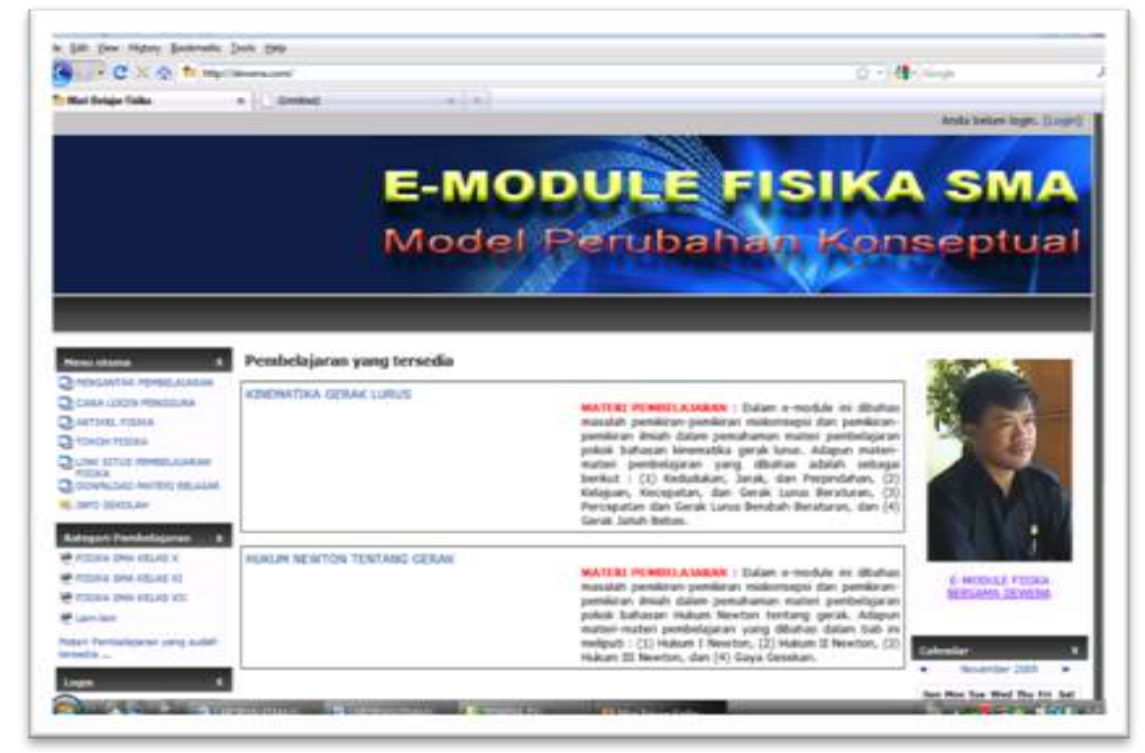

Gambar 02 : Screenshot homepage produk prototipe $e$-module fisika

Sebagai wujud dari penggunaan pendekatan user friendly dengan model Interactive Conceptual Instruction (ICI), e-module yang dihasilkan didesain atas 12 bagian pengaturan utama, yaitu (1) pengaturan menu utama pada halaman muka (Homepage), (2) pengaturan login pengguna melalui halaman login, (3) Pengaturan komunikasi pembelajaran melalui link daftar Pembelajaran yang tersedia, (4) pengaturan tampilan Topik pembelajaran pada setiap pokok bahasan, (5) penyampaian indicator pembelajar pada halaman Indikator pembelajaran, (6) penyampaian materi pembelajaran pada halaman materi pembelajaran, (7) penyampaian contoh soal melalui halaman contoh-contoh Soal, (8) pemberian kesempatan kepada siswa untuk berdiskusi melalui fasilitas forum untuk mengerjakan lembar kerja siswa, (9) pemberian tugas pembelajaran yang 
disampaikan melalui halaman penugasan, (10) melakukan evaluasi pembelajaran secara real-time melalui halaman evaluasi, (11) mengelola keberadaan user-user yang terlibat dalam pembelajaran melalui halaman User, dan (12) pengelolaan nilai siswa oleh guru atau administrator melalui halaman nilai.

\section{Hasil Evaluasi Kelayakan Prototipe E-module}

Evaluasi kelayakan pakai prototipe e-module bermuatan model perubahan konseptual dalam pembelajaran fisika SMA dilakukan melalui evaluasi formatif testing dengan melibatkan pakar dan pengguna. Hasil evaluasi kelayakan menyatakan bahwa rata-rata skor kelayakan prototipe e-module yang berikan oleh para pakar dan pengguna adalah sebesar 3,78 dan berada dalam kategori sangat baik. Rangkuman hasil evaluasi oleh para pakar dan pengguna dapat dilihat pada tabel 01.

Tabel 01 : rangkuman hasil evaluasi kelayakan prototipe e-module

\begin{tabular}{|c|c|c|c|}
\hline No & EVALUATOR & RATA-RATA SKOR & KRITERIA \\
\hline $\mathbf{1}$ & Ahti Pembelyjaran Fs'ta & 3,90 & Sanget Bait \\
\hline 2 & AhtiMedia Pembelajaran & 3,77 & Sangat $B a=$ \\
\hline 3 & Ahti Telnologi Pembelajaran & 3,75 & Sanget Ba?t \\
\hline 4 & Ahis Pemrograman E-keaming & 3,71 & Oulup Bât \\
\hline 5 & Guru Fs'ta sehagai Pengouna & 3,78 & Sanget Bait \\
\hline 6 & Siswa Sehagi Penggua & 3,77 & Sanget Bait \\
\hline & TOTAL & 3,78 & Sangat Baik \\
\hline
\end{tabular}

Sedangkan validasi produk melalui pendekatan summative testing berbasis signifikansi perbedaan antara skor-skor pretest dan posttest, diperoleh rata-rata skor pretest 5,35 dengan simpangan baku 0,87 dan rata-rata skor posttest 8,40 dengan simpangan baku 0,68. Dengan mempergunakan uji-t, diperoleh bahwa untuk taraf kepercayaan $95 \%$ rata-rata skor pretest dan rata-rata skor posttest berbeda secara signifikan, artinya prestasi belajar siswa setelah menggunakan e-module lebih baik dari sebelum menggunakan $e$-module. 


\section{Pembahasan}

Berdasarkan evaluasi kelayakan yang dilakukan oleh para ahli pembelajaran fisika, ahli media pembelajaran, ahli teknologi pembelajaran, ahli pemrograman, guru fisika, dan siswa kelas X SMA sebagai pengguna terhadap prototipe e-module diperoleh bahwa kualifikasi penilaian para evaluator terhadap kualitas kelayakan $e$ module berada dalam kualifikasi sangat baik, dengan rata-rata skor penilaian sebesar 3,78 dari skor maksimal ideal 4,00. Karena evaluasi dilakukan setelah para ahli dengan memanfaatkan e-module model perubahan konseptual dalam pembelajaran fisika di SMA, maka diyakini bahwa penilaian dari para ahli dan para pengguna telah mencerminkan kelayakan kualitas dari prototipe e-module yang sesungguhnya. Dengan demikian secara prinsip e-module fisika bermuatan model perubahan konseptual yang dihasilkan diyakini akan memberikan manfaat secara fleksibel dalam proses pembelajaran, mengakomodasi belajar mandiri para siswa, dan secara umum dapat memberikan efesiensi biaya pendidikan, sehingga produk ini dapat dipergunakan sebagai fasilitas belajar bagi sekolah dan siswa SMA dalam membangun pemahaman konsep secara mendalam dan kemampuan pemecahan masalah fisika yang memadai. Kondisi ini sejalan hasil evaluasi summative testing yang mennyatakan bahwa terjadi perbedaan yang positif dan signifikan antara ratarata skor pretest dan posttest dari uji coba implementasi e-module pada sampel penelitian.

Sejalan dengan keberhasilan pengembangan prototipe e-module fisika bermuatan model perubahan konseptual dalam pembelajaran fisika di SMA, maka diharapkan dapat dikembangkan dan dimanfaatkan secara lebih luas baik dalam konteks bidang studi, tingkatan kelas, maupun tingkatan sekolah, sehingga tujuan pengembangan e-learning di jenjang pendidikan dasar dan menengah dapat terwujud.

\section{SIMPULAN DAN SARAN}

\section{Simpulan}

Bertitik tolak dari pencapaian target yang harus dicapai, memperhatikan hasil yang diperoleh dan evaluasi kelayakan yang dilakukan terhadap pencapaian target, maka dapat disimpulkan sebagai berikut : 
a. Telah dihasilkan prototipe e-module fisika bermuatan model perubahan konseptual untuk pembelajaran fisika pada jenjang pendidikan SMA yang dapat diadaptasi kembali oleh siapa saja, dimana saja, dan kapan saja untuk pengajaran bidang studi lain, untuk jenjang kelas dan jenjang pendidikan yang berbeda.

b. Evaluasi terhadap kelayakan prototipe e-module bermuatan model perubahan konseptual yang dilakukan oleh ahli pembelajaran fisika, ahli media pembelajaran, ahli teknologi pembelajaran, ahli pemrograman, guru fisika, dan siswa sebagai pengguna menunjukkan bahwa rata-rata skor kelayakan prototipe e-module sebesar 3,78 dengan kualitas sangat baik.

c. Hasil uji coba pemanfaatan e-module menunjukkan bahwa rata-rata skor pretest 3,53 dan rata-rata skor posttes 8,40 berbeda secara signifikan pada taraf kepercayaan $95 \%$.

\section{Saran}

Berdasarkan hasil dan temuan dalam penelitian ini, maka dapat diberikan saran-saran sebagai berikut :

a. Prototipe e-module fisika bermuatan model perubahan konseptual yang dihasilkan hanya berisikan materi tentang kinematika gerak lurus dan hukum newton tentang gerak, oleh karena itu perlu dikembangkan lebih jauh lagi untuk mater-materi fisika lainnya.

b. Prototipe $e$-module yang dihasilkan berfokus pada pembelajaran fisika bermuatan model perubahan konseptual, oleh karena itu perlu dikembangkan $e$-module yang berfokus pada pembelajaran bidang studi yang lainnya.

c. Untuk menemukan pengaruh penggunaan $e$-module bermuatan model perubahan konseptual dalam pembelajaran fisika, maka perlu dilakukan pengembangan yang lebih mendalam dan melakukan uji coba di beberapa sekolah, sehingga nantinya diperoleh e-module bermuatan model perubahan konseptual dalam pembelajaran yang layak mendapatkan hak kekayaan intelektual. 


\section{DAFTAR PUSTAKA}

Brooks, J.G. \& Martin G. Brooks. 1993. In search of understanding: The case for constructivist classrooms. Virginia: Association for Supervision and Curriculum Development.

Burden, P. R., \& Byrd, D. M. 1999. Method for effective teaching, second edition. Boston: Allyn and Bacon.

Dick, W., \& Carey, L. 1990. The systematic design of instruction, $3^{\text {rd }}$. Lilinois: Harper Collins Publisher.

Gay, L. R. 1987. Education research, Competencies for analysis and application. Third edition. Columbus: Merrill Publishing Company.

Keegan, D. 1993. Theoretical priciples of distance education. London \& New York: Routledge.

Montgomery, D. C. 1984. Design and analysis of experiment. Second edition. New York: John Wiley \& Sons.

Riduwan, 2003. Dasar-dasar Statistika, Cetakan keempat. Badung : CV Alfabeta Bandung.

Santosa Singgih, 2000. SPSS Statistik Parametrik (Buku latihan). Cetakan kedua. Jakarta : PT Elex Media Komputindo.

Santyasa, I W., Suwindra, I N P., Sujanem, R., \& Suardana, I K. 2005. Pengembangan teks fisika bermuatan model perubahan konseptual dan komunitas belajar serta pengaruhnya terhadap perolehan belajar siswa SMA. Laporan Penelitian RUKK tahun I 2005. Lembaga Penelitian IKIP Negeri Singaraja.

Sugiyono, 2010. Metode Penelitian Kuantitatif, Kualitatif, dan $R \&$ D. Cetakan ke10. Bandung : AlfaBeta Bandung. 